Can J. Fish Aquat Sci. 40, 206-214.

Waldock, M. J., Waite, M. E., Miller, D., Smith, D. J. \& Law, R. J (1989). The determination of total tin and organotin compounds in environmental samples. Aquat. Environ. Prot.: Analyt. Meth., MAFF Direct. Fish. Res., Lowestoft
Wassermann, M., Wassermann, D., Cucos, S. \& Miller, H. J. (1979). World PCBs map: Storage and effect in man and his biologic environment in the 1970's. In Health Effects of Halogenated Aromatic Hydrocarbons (W. J. Nicholson \& J. A. Moore, eds), Ann. NY Acad. Sci, 320,69-124.

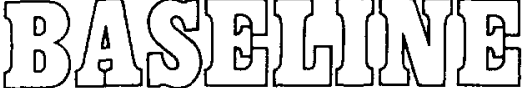

Edited by E. I. Hamilton
The objective of BASELINE is to publish short communications for the concentration and distribution of elements and compounds in the marine environment. Only those papers which clearly identify the quality of the data will be considered for publication. Contributors to Baseline should refer to 'Baseline-A Record of Contamination Levels' (Mar. Pollut. Bull. 13, 217-218).

\section{Chemical Contamination of French Coasts}

\section{The Results of a Ten Years Mussel Watch}

Since 1979 , a mussel watch programme, the National Network for the Observation of the Quality of the Marine Environment (Réseau National d'Observation, R.N.O.) has been carried out on bivalves from the French shore. Concentration levels of metal $(\mathrm{Hg}, \mathrm{Cd}$, $\mathrm{Pb}$ ) and organic contaminants (PAH, PCB, DDT, DDD, DDE) have been determined on soft parts of mussels and oysters sampled on a quarterly basis. A summary of methods, data validation scheme used, and the results obtained are given. Hot spots, particularly in the Gironde estuary for $\mathrm{Cd}$ and in the Bay of the Seine for PCBs are identified.

It is now recognized that the monitoring of certain contaminants in molluscs is an effective way of assessing the contamination levels of the marine environment, providing certain precautions are taken (Goldberg, 1975; Phillips, 1977, 1978; Cossa, 1989). Since 1979 the Ministry of the Environment in France has financed a monitoring programme to determine contamination levels in French coastal waters, using mussels and oysters as quantitative indicator species. This mussel watch is called the "National Network for the Observation of the Quality of the Marine Environment" (R.N.O.). Planning and undertaking have been entrusted to the Institut Français de Recherche pour l'Exploitation de la Mer (IFREMER). The results of ten years of monitoring of mercury, cadmium, lead, total polycyclic aromatic hydrocarbons (PAH), polychloro-diphenyls (PCBs), and dichloro-diphenyl- chloroethanes (p,p'DDT, p,p'DDD, p,p'DDE) in the soft tissues of molluscs are summarized.

The network comprises 110 sampling stations along the entire length of the French coastline (Fig. 1). Samples are taken in February, May, August and November. Three species are used: Mytilus edulis, Mytilus galloprovincialis, and Crassostrea gigas.

The samples always consist of the same species for a given station, and always fall within the same size or age range (35-60 mm for mussels; 2 years for oysters), as recommended by the guidelines of the Joint Monitoring Group of Oslo and Paris Conventions. They consist of a sufficient number of individuals to minimize the effect of individual variations ( $N>50$ for mussels and $N>10$ for oysters), and always came from the same intertidal zone.

The bivalves are cleaned of epibiota with sea water at the sampling site, and then depurated for $24 \mathrm{~h}$ in decanted sea water from the collection site in order to eliminate faeces and pseudofaeces. They are sized and shucked from their shell with a stainless steel scalpel. The molluscs are drained for $2 \mathrm{~h}$ using a porcelain Buchner funnel, poured into a small glass container, and frozen. They are then brought to the IFREMER laboratory for chemical analyses. After thawing out, the samples are ground and homogenized in a Virtis grinder and freeze-dried.

Mercury is determined by flameless atomic absorption spectrophotometry (Thibaud, 1983a). The other metals are determined by atomic absorption spectrophotometry equipped with an electrothermal atomization (Thibaud, 1983b). Total polycyclic aromatic hydrocarbons are analysed by HPLC using spectrofluorimetric detection (Michel, 1983). Organochlorine compounds are analysed by gas-chromatography involving electron capture (Luçon \& Michel, 1986). The results obtained are expressed in $\mathrm{mg} \mathrm{kg}^{-1}$ dry wt for the metals and the PAHs, and in $\mu \mathrm{g} \mathrm{kg}^{-1}$ dry wt for the organochlorines. The data are archived in the form of a data base using a Bull DPS7000 computer.

Any environmental monitoring programme must be supported by a quality assurance programme including a data validation process (Goldberg, 1985). The validation conducted within the framework of the R.N.O. has followed the principles described by Taylor (1986): the assurance that the samples are representative; the 


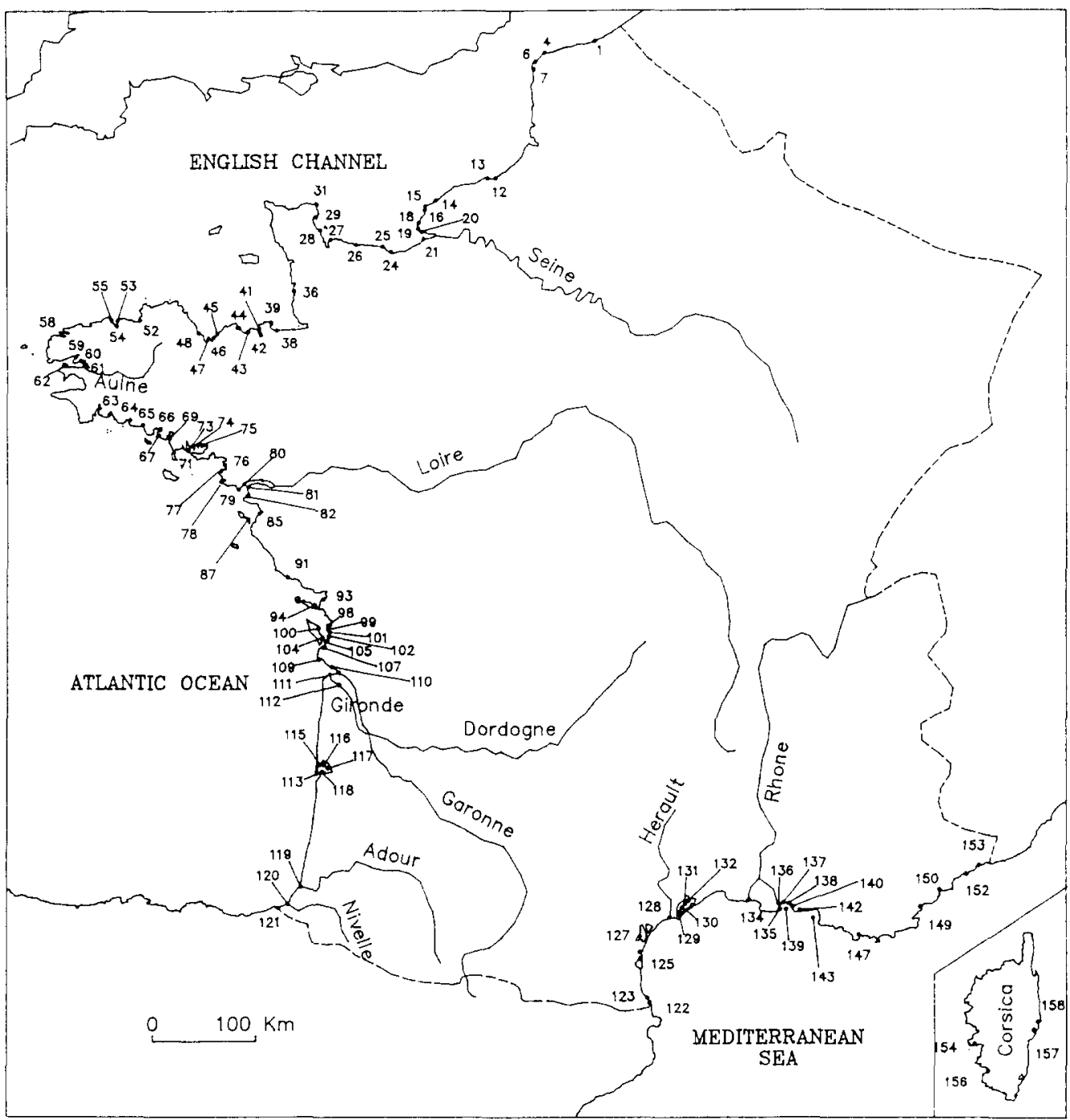

Fig. 1 Sampling sites.

systematic use of reference samples; the participation of the laboratory in international intercalibration activities, in particular in those organized by the International Council for the Exploration of the Sea (ICES); the discarding of certain series of measurements on account of known objective causes; the systematic application of statistical tests to all the data according to a described method (Natrella, 1966).

The results of Michel \& Marchand (1988) do not show any bioaccumulation difference between the species with regard to organic contaminants. A singificant difference appears for cadmium; in contaminated environments oysters accumulate about three times as much of this metal as mussels (Boutier et al., 1989). For other elements it is not possible to arrive at any conclusions owing to the insufficiency of comparative data.

Since 1979, 20000 data have been acquired. Table 1 shows the minimum and maximum values found according to the species used. Figures 2-7 present the station averages.

The lowest values fall within the concentration levels considered as natural in the literature. Several sites, however, are distinguished from the rest by higher concentrations, which are identified below. For each hot spot, range of concentration and average value are given with the station number.

Mercury: The mouth of the Nivelle, at Saint-Jean-de-
TABLE 1

Concentration (dry wt) range found on the French coast. $\mathrm{N}=$ number of observations. PCBs are expressed by reference to Arochlor 1254.

\begin{tabular}{|c|c|c|c|c|}
\hline & & Min. & Max. & $N$ \\
\hline $\mathrm{Hg}$ & Mussels (mg kg-1) & $<0.02$ & 0.83 & 1341 \\
\hline $\mathrm{Hg}$ & Oysters (mg kg-1) & 0.03 & 1.66 & 980 \\
\hline $\mathrm{Cd}$ & Mussels (mg kg${ }^{-1}$ ) & 0.10 & 36.20 & 1458 \\
\hline $\mathrm{Cd}$ & Oysters (mg kg $\mathrm{k}^{-1}$ ) & 0.25 & 129.10 & 1036 \\
\hline $\mathrm{Pb}$ & Mussels (mg kg${ }^{-1}$ ) & $<0.10$ & 21.40 & 1451 \\
\hline $\mathrm{Pb}$ & Oysters (mg kg-1) & $<0.10$ & 8.90 & 1017 \\
\hline PAH & Mussels (mg kg-1) & $<0.10$ & 303.00 & 1488 \\
\hline $\mathrm{PAH}$ & Oysters (mg kg-1) & $<0.10$ & 69.50 & 1062 \\
\hline PCB & Mussels ( $\mu \mathrm{g} \mathrm{kg}^{-1}$ ) & $<20.0$ & 10427.00 & 1498 \\
\hline PCB & Oysters $\left(\mu \mathrm{gg}^{-1}\right)$ & $<25.0$ & 2280.00 & 1075 \\
\hline DDT & Musseis ( $\mu \mathrm{g} \mathrm{kg}^{-1}$ ) & $<0.4$ & 590.00 & 1452 \\
\hline DDT & Oysters $\left(\mu \mathrm{kg}^{-1}\right)$ & 1.0 & 728.00 & 1066 \\
\hline DDD & Mussels ( $\mu \mathrm{kg}^{-1}$ ) & $<0.5$ & 219.00 & 1477 \\
\hline $\mathrm{DDD}$ & Oysters $\left(\mu g \mathrm{~kg}^{-1}\right)$ & $<0.6$ & 487.00 & 1076 \\
\hline DDE & Mussels ( $\mu \mathrm{g} \mathrm{kg}^{-1}$ ) & $<0.1$ & 222.40 & 1477 \\
\hline DDE & Oysters $\left(\mu \mathrm{kg}^{-1}\right)$ & 1.0 & 252.00 & 1061 \\
\hline
\end{tabular}

Luz (St. 120; range: $0.16-1.66 \mathrm{mg} \mathrm{kg}^{-1}$; average $=0.56$ ), the Fécamp region (St. 14 ; range: $0.18-0.83 \mathrm{mg}$ $\mathrm{kg}^{-1}$; average $=0.41$ ), the Saint-Gervais headiand in the Gulf of Fos (St. 138; range: $0.21-0.66 \mathrm{mg} \mathrm{kg}^{-1}$; 


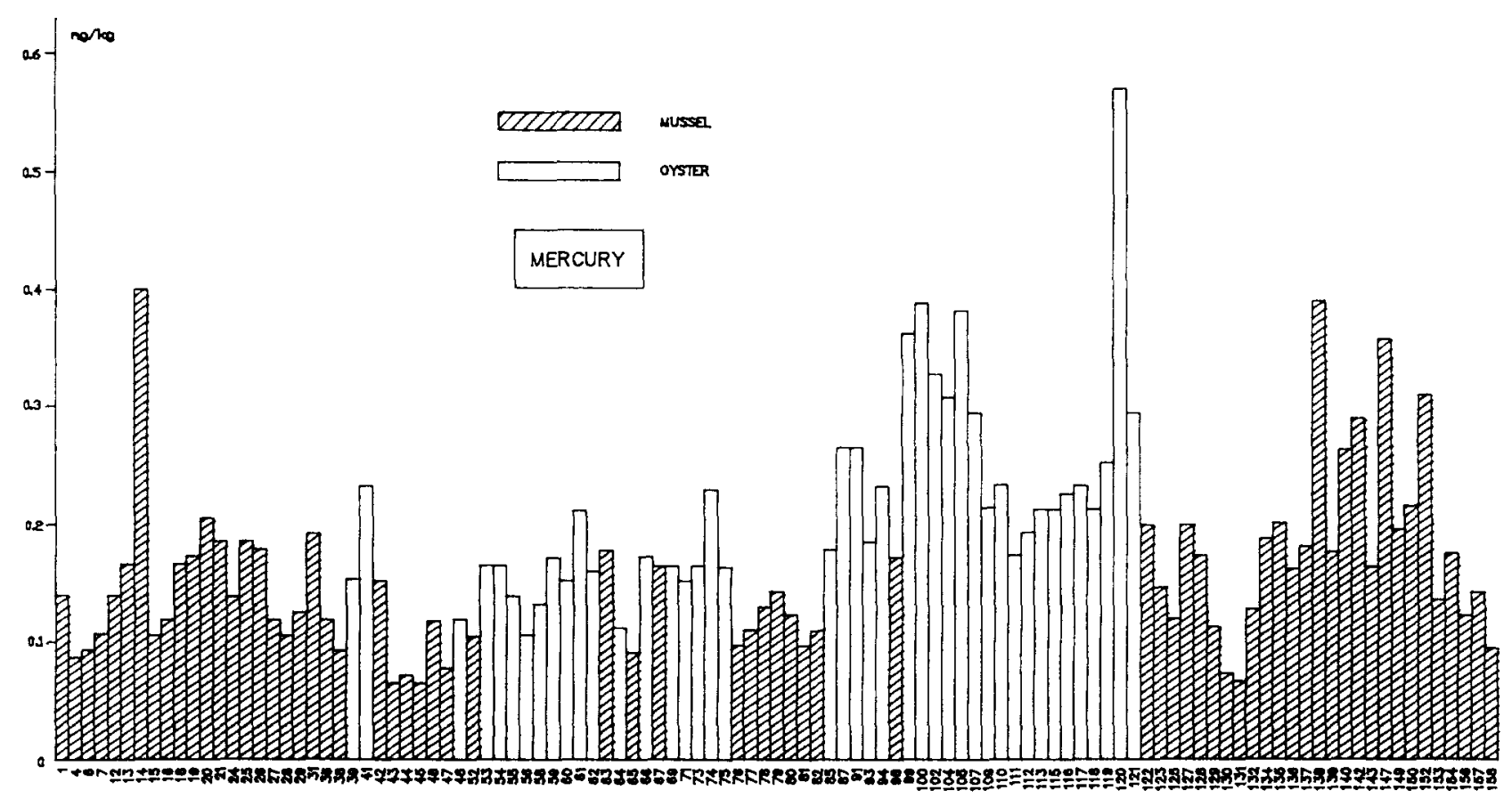

Fig. 2 Average of mercury (mg kg-1 dry wt) station by station, from 1979 to 1988 . Stations are geographically arranged from north to south.

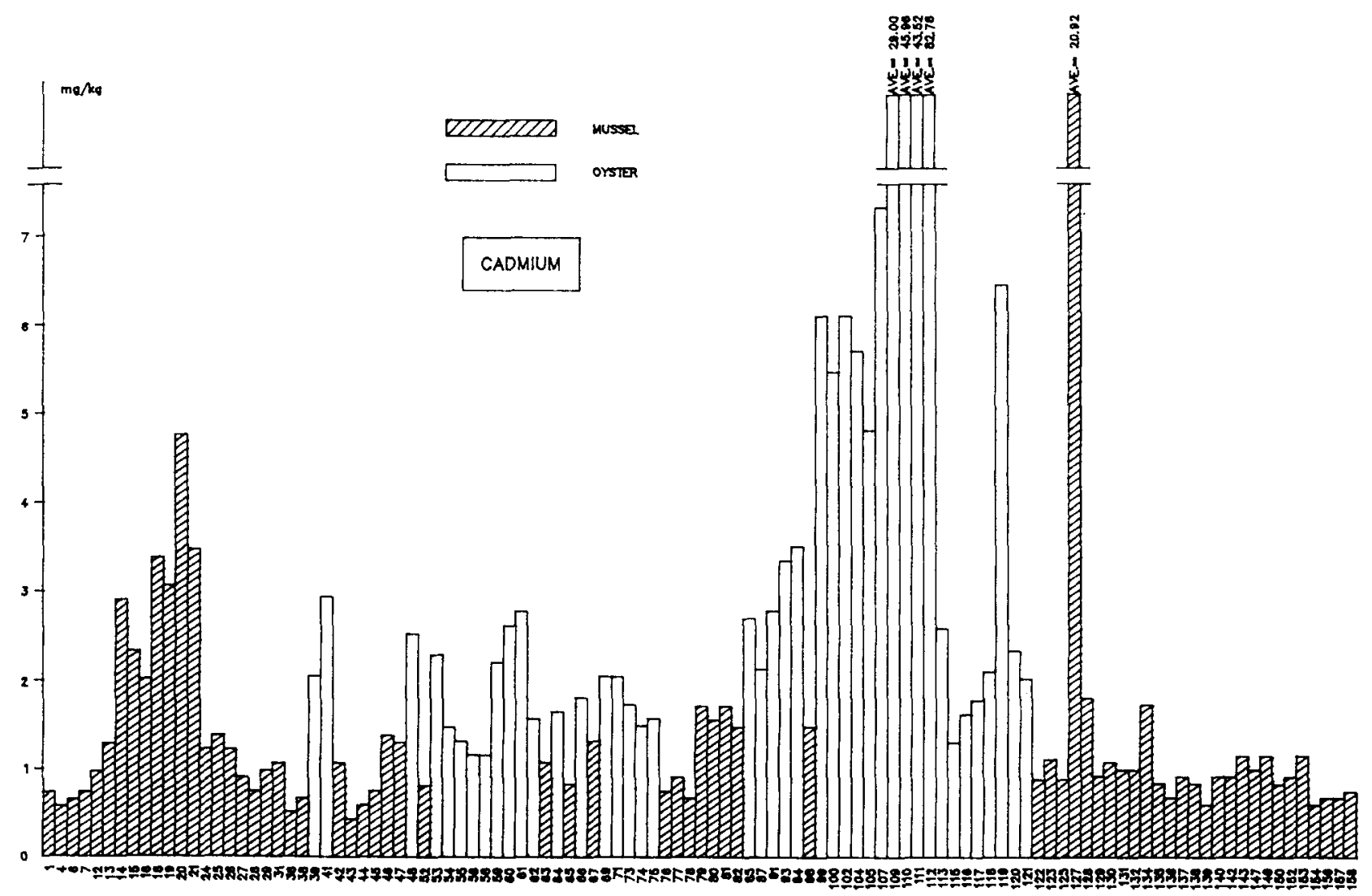

Fig. 3 Average of cadmium (mg kg-1 dry wt) station by station, from 1979 to 1988 . Stations are geographically arranged from north to south.

average $=0.38$ ), Toulon harbour (St. 147; range: 0.20 $0.65 \mathrm{mg} \mathrm{kg}^{-1}$; average $=0.37$ ), the Marennes-Oléron basin (St. 99 to 107; range: $0.08-0.81 \mathrm{mg} \mathrm{kg}^{-1}$; average $=0.33$ ), and the Bay of Villefranche-sur-mer (St. 152 ; range: $0.16-0.49 \mathrm{mg} \mathrm{kg}^{-1}$; average $=0.33$ ).

Cadmium: The Gironde estuary (St. 109 to 112 ; range: $10.20-129.10 \mathrm{mg} \mathrm{kg}^{-1}$; average $=52.11$, which constitutes the most important environmental problem brought to light by the mussel watch (Boutier \& Chiffoleau, 1986), Bages pond (St. 127; range: 11.60-36.20 $\mathrm{mg} \mathrm{kg}^{-1}$; average $=20.92$ ), the mouth of the Adour (St. 119; range: $3.00-12.30 \mathrm{mg} \mathrm{kg}^{-1}$; average $=6.42$ ), the Marennes-Oléron basin (St. 99 to 107; range: 2.21$14.10 \mathrm{mg} \mathrm{kg}^{-1}$; average $=6.07$ ), and the Bay of the 


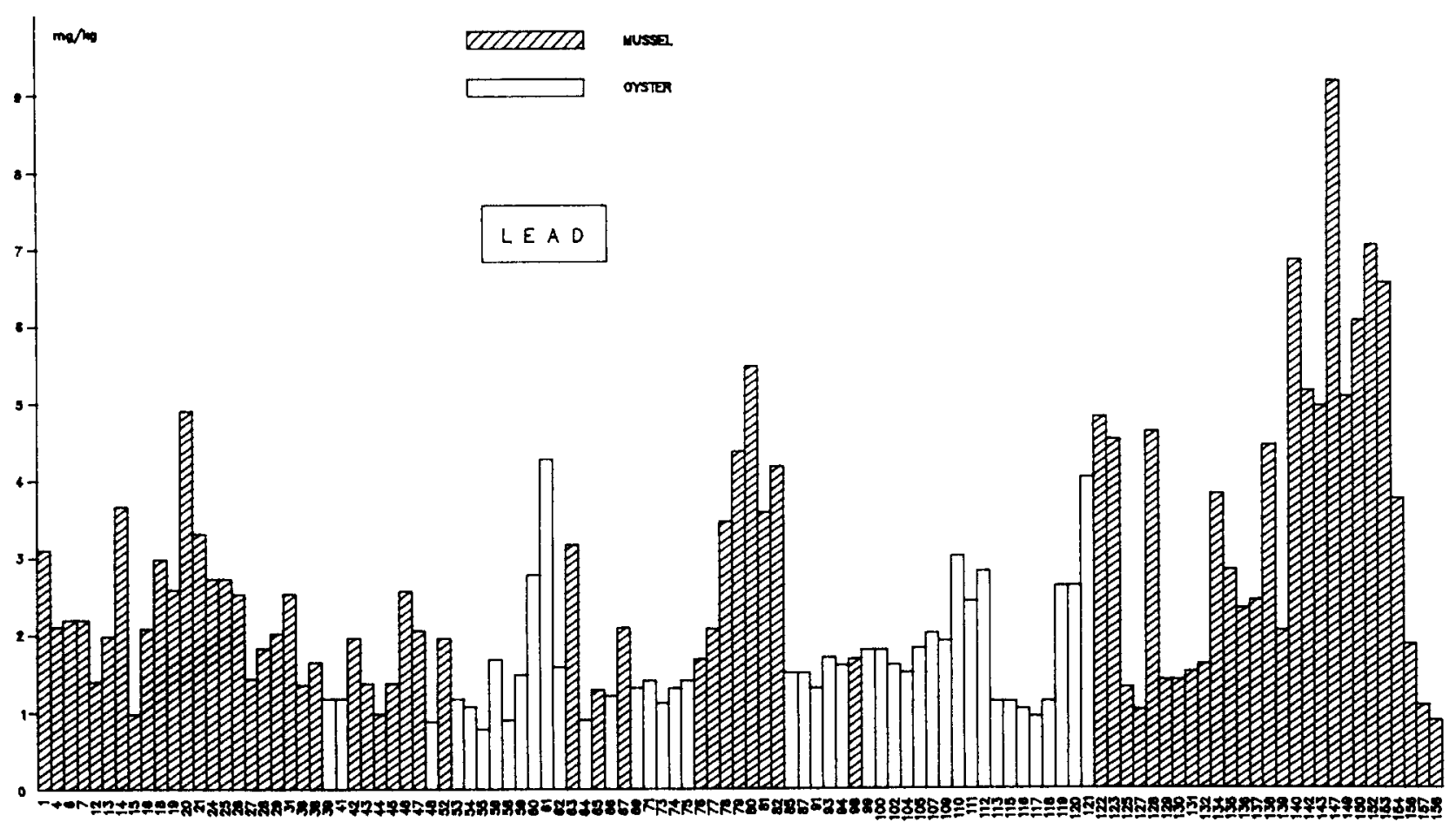

Fig. 4 Average of lead (mg kg-1 dry wt) station by station, from 1979 to 1988 . Stations are geographically arranged from north to south.

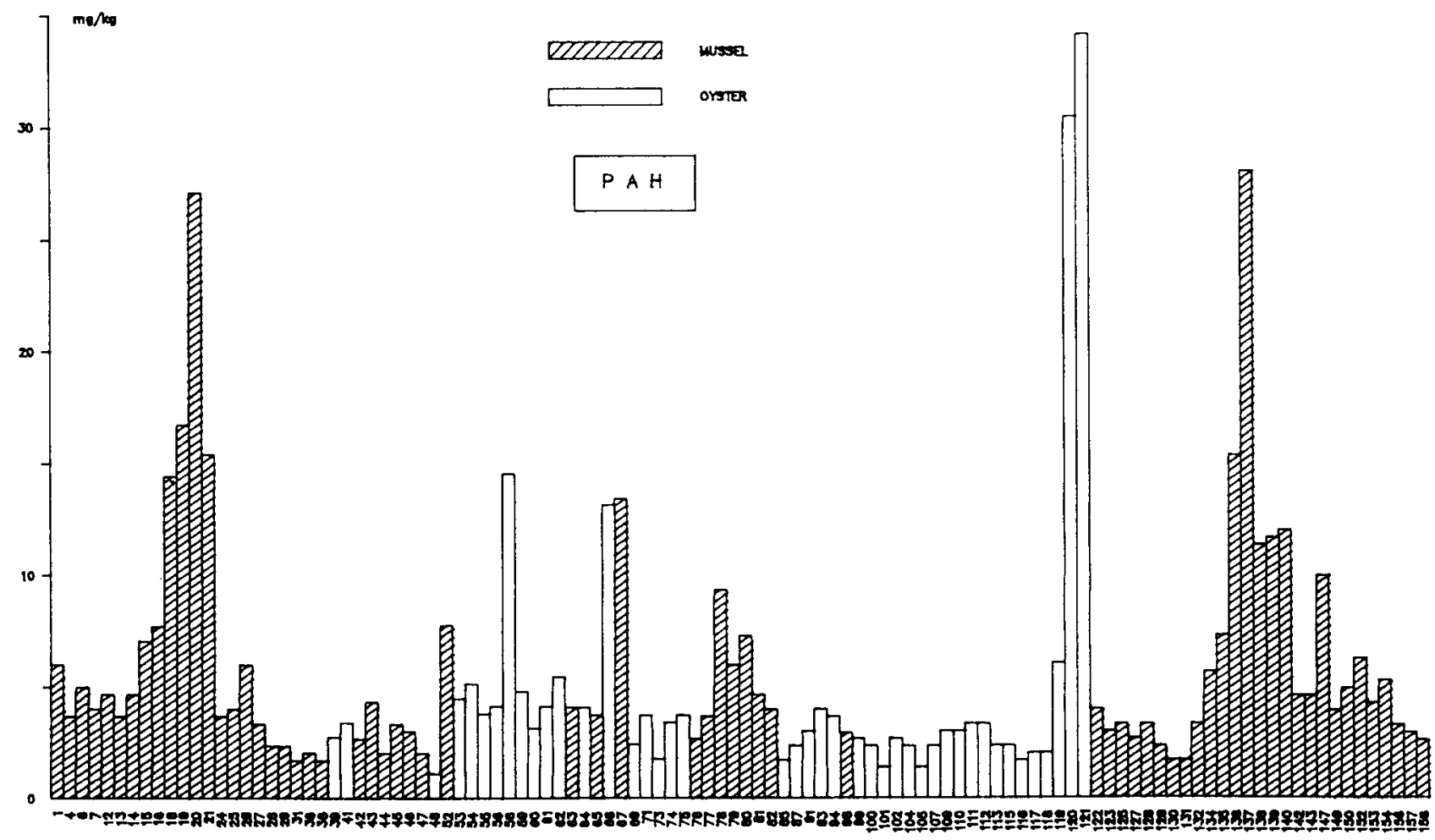

Fig. 5 Average of PAH (mg kg-1 dry wt) station by station, from 1979 to 1988. Stations are geographically arranged from north to south.

Seine (St. 18 to 21 ; range: $0.63-8.79 \mathrm{mg} \mathrm{kg}^{-1}$; average $=3.48$ ).

Lead: All sites monitored on the Mediterranean coast from the Gulf of Fos to Italy (St. 138 to 153; range: $0.46-19.70 \mathrm{mg} \mathrm{kg}^{-1}$; average $=6.30$ ), the mouth of the Hérault (St. 128; range: $2.60-7.00 \mathrm{mg} \mathrm{kg}^{-1}$; average $=5.03$ ), the region of Banyuls-sur-mer (St. 122 and 123 ; range: $1.40-9.40 \mathrm{mg} \mathrm{kg}^{-1}$; average $=4.64$ ), the Loire estuary (St. 79 to 82 ; range: $1.50-10.70 \mathrm{mg}$ $\mathrm{kg}^{-1}$; average $=4.41$ ), the mouth of the Aulne (St. 61; range; $0.80-8.90 \mathrm{mg} \mathrm{kg}^{-1}$; average $=4.26$ ), Hendaye (St. 121 ; range: $1.80-6.30 \mathrm{mg} \mathrm{kg}^{-1}$; average $=3.90$ ), the Seine estuary (St. 20 and 21 ; range: $1.20-8.10 \mathrm{mg} \mathrm{kg}^{-1}$; average $=3.76$ ), the mouth of the Rhône (St. 134; range: $1.03-9.90 \mathrm{mg} \mathrm{kg}^{-1}$; average $=3.74$ ), the Fécamp region (St. 14 ; range: $1.60-5.50 \mathrm{mg} \mathrm{kg}^{-1}$; average $=$ 


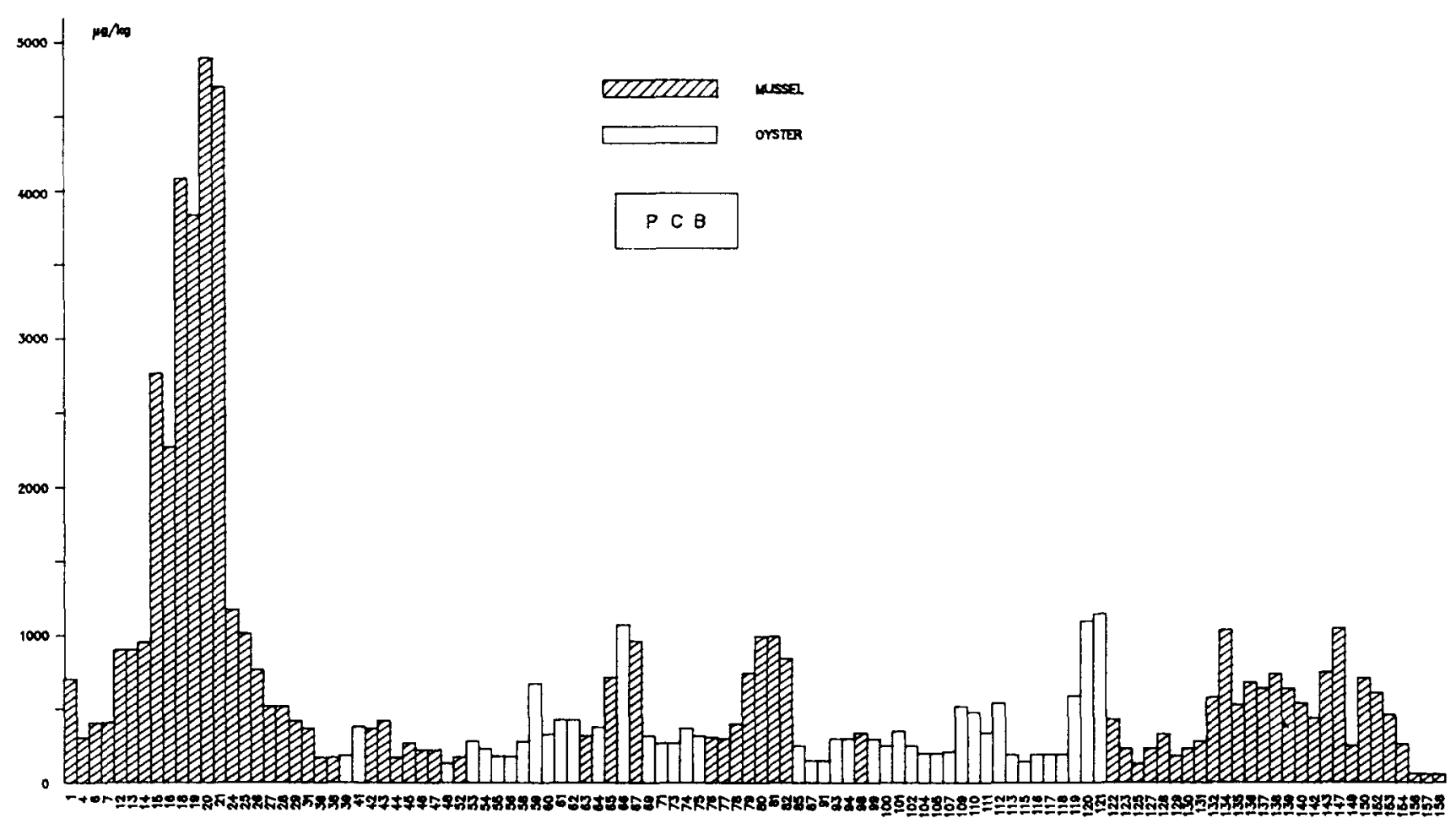

Fig. 6 Average of PCBs ( $\mu \mathrm{g} \mathrm{kg}^{-1}$ dry wt) station by station, from 1979 to 1988 . Stations are geographically arranged from north to south.

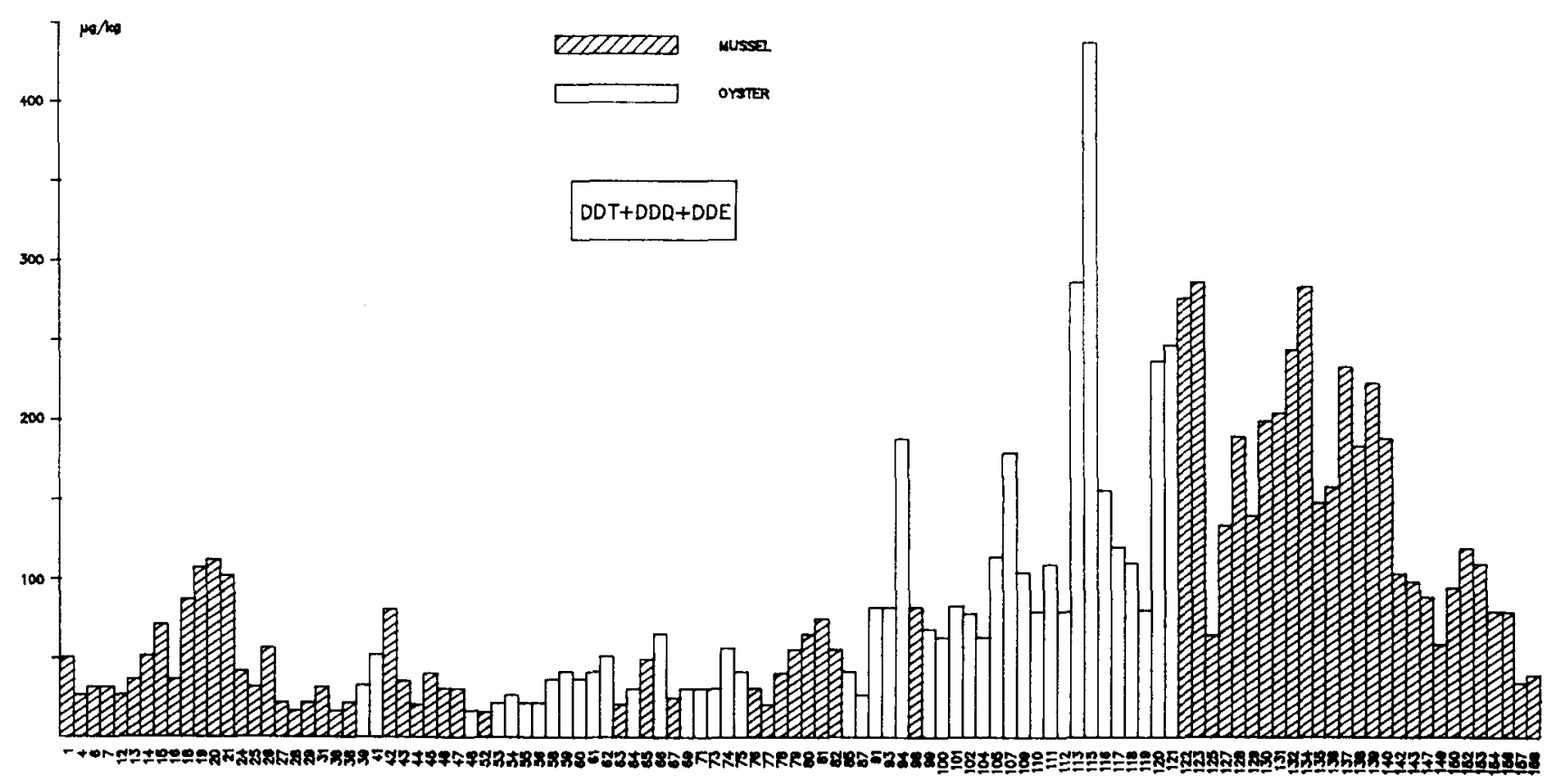

Fig. 7 Average of DDT+DDD+DDE ( $\mu \mathrm{g} \mathrm{kg}^{-1} \mathrm{dry}$ wt) station by station, from 1979 to 1988 . Stations are geographically arranged from north to south.

3.74), the Bay of Ajaccio in Corsica (St. 154; range: $0.21-8.50 \mathrm{mg} \mathrm{kg}^{-1}$; average $=3.64$ ).

PAH: Hendaye (St. 121; range: $14.92-66.20 \mathrm{mg}$ $\mathrm{kg}^{-1}$; average $=34.05$ ), the Nivelle (St. 120; range: $11.12-69.50 \mathrm{mg} \mathrm{kg}^{-1}$; average $=30.56$ ), the Seine estuary (St. 18 to 21 ; range: $4.70-51.70 \mathrm{mg} \mathrm{kg}^{-1}$; average $=17.02$ ), the Gulf of Fos (St. 136 to 140; range: $1.32-131.00 \mathrm{mg} \mathrm{kg}^{-1}$; average $=15.40$ ), the aber Benoit (St. 58 ; range: $2.29-43.00 \mathrm{mg} \mathrm{kg}{ }^{-1}$; average $=14.52$ ) which was very heavily contaminated in March 1978 following the wreck of the Amoco Cadiz and which is slowly recovering, and Lorient harbour (St. 66 and 67; range: $3.10-38.50 \mathrm{mg} \mathrm{kg}^{-1}$; average $=13.39$ ).

$P C B$ : The Bay of the Seine which seems to be one of the most polluted areas in Europe (St. 15 to 25; range: 271-10 $427 \mu \mathrm{g} \mathrm{kg}^{-1}$; average $=3279$ ), Hendaye (St. 121; range: $539-2109 \mu \mathrm{g} \mathrm{kg}^{-1}$; average $=1130$ ), the Nivelle (St. 120; range: $500-2032 \mu \mathrm{g} \mathrm{kg}{ }^{-1}$; average $=1108$ ), Toulon harbour (St. 147; range: $299-$ $3746 \mu \mathrm{g} \mathrm{kg}^{-1}$; average $=1104$ ), the Loire estuary (St. 80 and 81 ; range: $314-1874 \mu \mathrm{g} \mathrm{kg}^{-1}$; average $=1069$ ), the Rhône delta (St. 134; range: 321-2766 $\mu \mathrm{g} \mathrm{kg}{ }^{-1}$; 
average $=1055$ ), Lorient harbour (St. 66 and 67; range: $362-2330 \mu \mathrm{g} \mathrm{kg}^{-1}$; average $\left.=1048\right)$.

$p, p^{\prime} D D T+p, p^{\prime} D D D+p, p^{\prime} D D E:$ The contamination levels present a very peculiar profile. Except in the Seine estuary (St. 18 to 21 ; range: $19.2-302.0 \mu \mathrm{g} \mathrm{kg}^{-1}$; average $=99.1$, all the averages from all the stations of the English Channel and the Atlantic down to the Loire (inclusive) are $<100 \mu \mathrm{g} \mathrm{kg}^{-1}$. Stations in the south of France are most contaminated, reaching a peak in the Arcachon basin (St. 113 to 118 ; range: $24.3-1015.0 \mu \mathrm{g}$ $\mathrm{kg}^{-1}$; average $=233.8$ ). The levels along the Mediterranean coast are also quite high (range: $7.4-733.0 \mu \mathrm{g}$ $\mathrm{kg}^{-1}$; average $=151.9$ )

The geographical and time density of the sampling, as well as the permanent nature of this mussel watch, have made it possible to gain significant knowledge about the contamination levels in French coastal waters and to identify the presence of a few hot spots. During the next stage, the continuation of this monitoring programme should enable insight to be gained concerning the evolution of these levels over time. It will permit environmental managers to evaluate any possible improvement or deterioration in the condition of French coastal waters.

The author wishes to thank Dr. D. Cossa, who encouraged him to write this note and provided helpful comments and suggestions. Thanks are due to Mr. L. Giboire for drawing.

D. CLAISSE

Institut Français de Recherche

pour l'Exploitation de la Mer,

Centre de Nantes, BP 1049,

F 44037 Nantes Cedex 01 (France)
Boutier, B. \& Chiffoleau, J. F. (1986). La contamination par le cadmium en Gironde et son extension sur le plateau continental. Rapport IFREMER. DERO-86.12-MR. 27 p.

Boutier, B., Jouanneau, J. M., Chiffoleau, J. F., Latouche, C. \& Phillipps, I. (1989). La contamination de la Gironde par le cadmium. Origine, extension, importance. Rapport scientifique et technique IFREMER. (in press)

Cossa, D. (1989). A review of the use of Mytilus spp. as quantitative indicators of cadmium and mercury contamination in coastal waters. Oceanolog. Acta. 12 (in press)

Goldherg, E. D. (1975). The mussel watch. A first step in global marine monitoring. Mar. Pollut. Bull. 6, 111-113.

Goldberg, E. D. (1985). Environmental numerologies. La mer. 23, 4142.

Luçon, M. \& Michel, P. (1986). Dosage des PCB, pesticides et determination de la quantité de matière extractible à l'hexane dans la chair de poisson. Rapport IFREMER. DERO-86-05-MR.

Michel, P. (1983). Dosage global des hydrocarbures aromatiques dans les organismes marins par CLHP-fluorescence. In Manuel des analyses chimiques en milieu marin. (A. Aminot \& M. Chaussepied, ed.), pp. 337-346. CNEXO, BNDO/DOCUMENTATION, Brest, France.

Michel, P. \& Marchand, M. (1988). Résultats de sept années de surveillance des polluants organiques (PCB, DDT, PAH) dans les moules et les huittes du littoral français. In RNO. Réseau national d'observation de la qualité du milieu marin. Dix années de surveillance 19741984. Document technique. IFREMER-Ministère de l'environnement. (in press)

Natrella, M. (1966). The treatment of outliers. In Experimental Statistics (J. Wiley \& Sons, ed.), pp. 17-1-17-6. National bureau of standards handbook no. 91, New York.

Phillips, D. J. H. (1977). The use of biological indicator organisms to monitor trace metal pollution in marine and estuarine environments: A review. Environ. Pollut. 13, 281-317.

Phillips, D. J. H. (1978). Use of biological indicator organisms to quantitate organochlorine pollutants in aquatic environments: A review. Environ. Pollut. 16, 167-229.

Taylor, J. K. (1986). On validation of analytical data. Mar. Chem. 18, $115-119$.

Thibaud, Y. (1983a). Dosage du mercure dans les organismes marins. In Manuel des analyses chimiques en milieu marin (A. Aminot \& $\mathrm{M}$. Chaussepied, eds.), pp. 243-249. CNEXO, BNDO/DOCUMENTATION, Brest, France.

Thibaud, Y. (1983b). Dosage de métaux (Cu, $\mathrm{Zn}, \mathrm{Fe}, \mathrm{Pb}, \mathrm{Cd}$ ) dans les organismes marins par absorbtion atomique. In Manuel des analyses chimiques en milieu marin (A. Aminot \& M. Chaussepied, eds.), pp. 263-273. CNEXO, BNDO/DOCUMENTATION, Brest, France.

\section{Butyltins in Sediment from Marinas and Waterways in Puget Sound, Washington State, USA}

No data on butyltin contamination of sediments from marinas in Puget Sound have so far been reported. Puget Sound, Washington has recently been designated as an estuary of national significance as part of the US Environmental Protection Agency's National Estuary Program and thus information of the status of TBT contamination is very timely.

Using a newly developed method for the analysis of butyltins (Krone et al., in press), an initial survey of butyltins in sediments from marinas in Puget Sound has been completed. Butyltins (tetrabutyltin, TBT, DBT and $\mathrm{MBT}$ ) were analysed in sediments from 7 marinas, 3 waterways and a non-urban reference site (Figs 1,2). The study was initiated and sediments collected by the
$0025-326 \mathrm{X} / 89 \$ 3.00+0.00$ O 1989 Pergamon Press plc

US Army Corps of Engineers, Seattle District, as part of the Puget Sound Dredged Disposal Analysis Program. The marinas were located in Bellingham, Washington (Bellingham Small Boat Basin, BSBB), in Everett, Washington (Fourteenth Street Boat Basin, FSBB), in Seattle, Washington (Shilshole Bay, SB; the Duwamish Anchor Marina, DA; the Duwamish Yacht Club, DYC; and Fisherman's Terminal, FT), and in Kenmore, Washington (Kenmore Marina, KM). Sediments from waterways near the entrances to the Bellingham BSBB (Squalicum Creek, SC) and Everett FSBB (Snohomish River, SR) were also sampled. In addition, sediments were collected in the Duwamish West Waterway (DWW) and at President Point (PP). The Duwamish West Waterway was chosen because it is a major urban waterway and an area of intense, industrial activity which includes shipping traffic, ship building, maintenance and repair facilities. President Point is a non-urban site (reference area) with no known sources of anthropogenic chemicals. The 